\title{
The Woodpile
}

\author{
In memoriam John McGahern
}

We worked our way through it log by log: three winters' worth of heat, precious light through the darkest nights, the darkest days.

You'd remarked you knew the very tree, that last June you stacked them in the barn the silver logs in their fret of moss.

You must have had the news already whistling from the woodpile's finished height your arms about your favoured black dog.

Paula Meehan (January 2016) 
Željka Doljanin and Máire Doyle - 9781526105059 Downloaded from manchesterhive.com at 04/26/2023 11:42:17AM 